\title{
A Protease that Participates in Yeast Cell Wall Lysis during Zymolyase Digestion ${ }^{\dagger}$
}

\author{
Kumpei Kitamura \\ The Research Laboratories of Kirin Brewery Co., \\ Takasaki, Gunma 370-12, Japan \\ Received February 9, 1982
}

\begin{abstract}
Zymolyase B decreased the turbidity of a yeast cell wall suspension by about $50 \%$ and caused release of peptide-mannan from the cell walls. However cell walls treated with the enzyme still maintained the cell shape. The effect of the enzyme on the cell walls was inhibited by yeast mannan and completely counteracted by treatment of the enzyme with DFP. The activity was not affected by $\mathrm{pH}$, but was considerably reduced by incubation of the enzyme at $55^{\circ} \mathrm{C}$ for $15 \mathrm{~min}$, a treatment that did not affect the proteolytic activity. Heat-treatment decreased the molecular weight of the enzyme from 29,000 to 22,500 and its sensitivity to yeast mannan. Yeast mannan caused noncompetitive inhibition of the proteolytic activity of the native enzyme and competitive inhibition of that of the heat-treated enzyme. Modification of tryptophan residues of Zymolyase B resulted in decreased sensitivity to yeast mannan and a decrease in the activity of the enzyme on yeast cell walls as well as heat-treatment. On the basis of these results, it is hypothesized that Zymolyase B binds to the cell wall mannans and changes their conformation, making the attached proteins susceptible to proteolysis, and then releases peptide-mannan from the cell walls.
\end{abstract}

Previsouly Zymolyase A and B were purified from ZYMOLYASE-60,000 as enzyme responsible for yeast cell lysis. Zymolyase A was found to be a $\beta$-1,3-glucanase with latent activity in lysis of yeast cells and Zymolyase B was found to be a protease that may change the structure of the yeast cell wall to facilitate the penetration of Zymolyase A. ${ }^{1)}$ This action of Zymolyase B was not observed with commercial proteases.

\section{MATERIALS AND METHODS}

Enzyme preparation. Zymolyase A and B were prepared as described previously. ${ }^{11}$ Heat-treated Zymolyase B was prepared by incubating the enzyme solution $(\mathrm{pH}$ 7.5) at $55^{\circ} \mathrm{C}$ for $15 \mathrm{~min}$.

Yeast cell walls $(Y C W)$. YCW were prepared from brewer's yeast, obtained from a brewhouse, by autolysis at $\mathrm{pH} 5.5$ and $45^{\circ} \mathrm{C}$ for $45 \mathrm{hr}$. The cell walls still maintained the shape of the cells, but did not contain any cytoplasmic materials.
Measurement of activity of $Y C W$. Activity on YCW was determined by two methods.

1) Activity decreasing the turbidity of a $\mathrm{YCW}$ suspension. A reaction mixture consisting of $2 \mathrm{ml}$ of $\mathrm{YCW}$ suspension $(15 \mathrm{mg} / \mathrm{ml}), 3 \mathrm{ml}$ of $0.05 \mathrm{M}$ Tris buffer $(\mathrm{pH} 7.5)$ and $1 \mathrm{ml}$ of enzyme solution, was incubated at $30^{\circ} \mathrm{C}$ for $2 \mathrm{hr}$ with gentle shaking. The mixture was diluted 5 times with water, and then the optical density (OD) of the diluted mixture was determined at $800 \mathrm{~nm}$. Activity is expressed as percentage decrease in OD.

2) Activity releasing peptide-mannan from $Y C W$. The reaction mixture described above was incubated at $30^{\circ} \mathrm{C}$ for $2 \mathrm{hr}$. Then the reaction was stopped by adding $5 \mathrm{ml}$ of $0.44 \mathrm{M}$ TCA solution. The mixture was stood at room temperature for $20 \mathrm{~min}$, and then centrifuged. The amino acid substance and carbohydrate contents of the supernatant were respectively determined by the Folin reagent method $^{2)}$ as tyrosine and the phenol-sulfuric acid method ${ }^{3)}$ as mannose. Activities were expressed as the amounts of amino acid substances or carbohydrates released.

Determination of proteolytic activity. Proteolytic activity was determined in two ways with insoluble and soluble substrates.

1) Activity on dyed collagen. ${ }^{4}$ A reaction mixture consisting of $5 \mathrm{ml}$ of HPA (Hide Powder Azure

$\dagger$ Part of this work was presented at the Annual Meeting of the Society of Fermentation Technology of Japan, Osaka, November 6, 1979. 
Calbiochem Co.) suspension $(5 \mathrm{mg} / \mathrm{ml}$, in $0.05 \mathrm{M}$ Tris buffer, $\mathrm{pH} 7.5$ ) and $1 \mathrm{ml}$ of enzyme solution was incubated at $30^{\circ} \mathrm{C}$ for $2 \mathrm{hr}$ with shaking. The mixture was filtered and the OD of the filtrate was determined at $590 \mathrm{~nm}$. Activity was expressed as increase in OD.

2) Activity on casein. A reaction mixture, consisting of $2 \mathrm{ml}$ of $1.5 \%$ casein solution, $3 \mathrm{ml}$ of $0.05 \mathrm{M}$ Tris buffer $(\mathrm{pH}$ 7.5) and $1 \mathrm{ml}$ of enzyme solution, was incubated at $30^{\circ} \mathrm{C}$ for $2 \mathrm{hr}$. Then the activity was measured as described in a previous report. ${ }^{1)}$

Determination of lytic activity on viable yeast cells. Lytic activity was determined as described in a previous report. ${ }^{5)}$

Determination of protein. Protein was determined by the method of Lowry et al. ${ }^{6}$ ) with egg albumin as a standard.

Analysis of sugar composition. The test sample was hydrolyzed in $1 \mathrm{~N}$ sulfuric acid at $100^{\circ} \mathrm{C}$ for $3 \mathrm{hr}$, and sugars in the hydrolyzate were measured by the alditolacetate method. ${ }^{7,8)}$

Amino acid analysis. Lyophilized sample was hydrolyzed with $6 \mathrm{~N} \mathrm{HCl}$ at $110^{\circ} \mathrm{C}$ for $24,48,72$ or $96 \mathrm{hr}$, and amino acids in the hydrolyzate were analysed with a JLC6AH Model automatic amino acid analyzer (JEOL). Cystine and cysteine were determined as analyzer (JEOL). the method of Moore. $\left.{ }^{9}\right)$ Tryptophan was determined by the method of Edelhoch. ${ }^{10}$ )

Determination of molecular weight. The molecular weight of peptide-mannan was determined by gel filtration on Sepharose CL-4B in $0.1 \mathrm{M} \mathrm{NaOH}$ solution. The molecular weight of protein was determined by SDS-polyacrylamide gel electrophoresis as described previously. ${ }^{1)}$

Modification of tryptophan residues of Zymolyase $B$. Tryptophan (Trp) residues of the enzyme were oxidized with N-bromosuccinimide (NBS). ${ }^{11)}$ The molar extinction coefficient of the enzyme at $280 \mathrm{~nm}$ was 41,165 , calculated assuming a MW of 29,000 . Ten $\mu \mathrm{l}$ of $0.01 \mathrm{M}$ NBS solution was added to $3 \mathrm{ml}$ of enzyme solution ( $13.8 \mu \mathrm{mol} / \mathrm{liter})$ in $0.1 \mathrm{M}$ acetate buffer ( $\mathrm{pH} \mathrm{5.0)}$ and then the OD at $280 \mathrm{~nm}$ was measured. Additions were continued stepwisely until there was no further decrease in OD. The amount of Trp oxidized was calculated as described by Patchornik et al. ${ }^{12)}$

Carbohydrate. Pachyman was prepared from Poria co$\cos$ as described previously. ${ }^{13)}$ Carboxymethyl (CM)pachyman was prepared by the method of Clarke et al. ${ }^{14)}$ Yeast mannan was prepared from brewer's yeast by the method of Haworth. ${ }^{15}$ )

\section{RESULTS}

Action of Zymolyase B on $Y C W$

As shown in Fig. 1, the percentage decrease

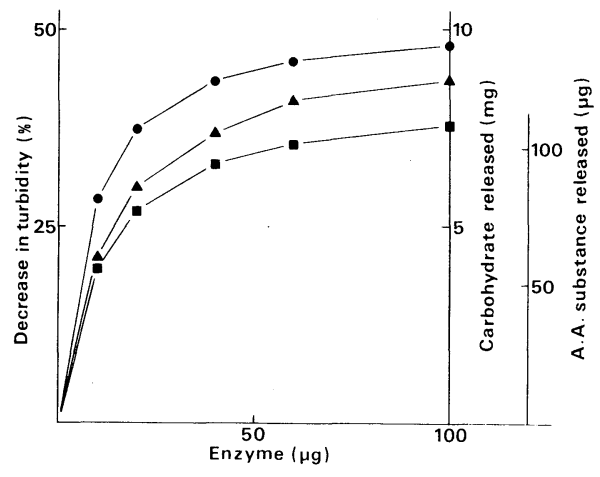

FIG. 1. Action of Zymolyase B on YCW.

Turbidity decrease and peptide-mannan release were determined with the indicated amounts of enzyme per $6 \mathrm{ml}$ of reaction mixture under the standard assay conditions. turbidity decrease; $\mathbf{\Delta}$, carbohydrate release; $\boldsymbol{\square}$, amino acid substance release.

TABle I. EFFECTS OF VARIOUS Carbohydrates on Turbidity DeCreasing Activity

Decrease in turbidity of YCW suspension was measured in the presence of $1 \%$ of each carbohydrate indicated using $15 \mu \mathrm{g}$ of enzyme per $6 \mathrm{ml}$ of reaction mixture under the standard assay conditions.

\begin{tabular}{lc}
\hline Carbohydrate & Inhibition $(\%)$ \\
\hline Starch & 0 \\
Dextran & 0 \\
CM-Cellulose & 0 \\
CM-Pachyman & 5 \\
Yeast mannan & 23 \\
Mannose & 0 \\
\hline
\end{tabular}

in turbidity of the YCW suspension increased with an increase in enzyme concentration to about $50 \%$ and then became constant. Under a microscope, cell walls in the reaction mixture became faint, but maintained the cell shape. No decrease in the number of YCW was observed. The enzyme also acted on YCW to release amino acid substances and carbohydrates, and the release of these substances were proportional to the turbidity decrease. The released material was isolated from the mixture by TCA treatment to remove protein, and then ethanol precipitation, dialysis and lyophilization. The material was peptide-mannan with an average molecular weight of approximately 180,000 and consisted of $10.4 \%$ pro- 
tein (as egg albumin) and $71.1 \%$ carbohydrate (as anhydromannose). Its sugar composition was $98 \%$ mannose and $2 \%$ glucose. Zymolyase $\mathrm{B}$ did not show mannanase activity.

Table I shows the effects of verious carbohydrates on the activity decreasing the turbidity of a YCW suspension. Yeast mannan inhibited the activity but other carbohydrates were not inhibitory. Zymolyase B lost its activity on YCW completely on treatment with $1 \mathrm{~mm}$ diisopropylfluorophosphate (DFP) at $20^{\circ} \mathrm{C}$ for $2 \mathrm{hr}$.

\section{Effect of $p H$ on the action on $Y C W$}

As shown in Fig. 2, Zymolyase B did not show any optimum $\mathrm{pH}$ for its action on $\mathrm{YCW}$, unlike in the case of proteolysis, ${ }^{1)}$ and the action was constant between $\mathrm{pH} 7.0$ and 12.0.

\section{Thermostability of the activity on $\mathrm{YCW}$}

As shown in Fig. 3, the enzyme lost much its activity on YCW when it was incubated at $55^{\circ} \mathrm{C}$ for $15 \mathrm{~min}$, although its proteolytic activity was increased rather than decreased by this treatment. On heat-treatment the enzyme also lost yeast cell lytic activity in the presence of Zymolyase $\mathrm{A}$, and its molecular weight decreased from 29,000 to 22,500 (Fig. 4). Table

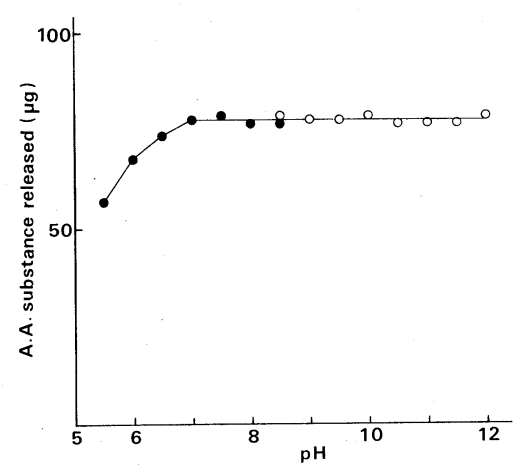

FIG. 2. Effect of $\mathrm{pH}$ on Peptide-mannan Releasing Activity.

Peptide-mannan releasing activity was measured with $20 \mu \mathrm{g}$ of enzyme per $6 \mathrm{ml}$ of reaction mixture and buffers of various pHs under the standard assay conditions. Activity is expressed as the amount of amino acid substance released. $0.05 \mathrm{~m}$ Tris-maleate- $\mathrm{NaOH}$ buffer; $\bigcirc, 0.1 \mathrm{~m}$ glycine- $\mathrm{NaOH}$ buffer.
II shows the results of amino acid analysis of the native and heat-treated enzymes.

\section{Effect of yeast mannan on proteolytic activity}

As shown in Fig. 5, the proteolytic activities of the native and heat-treated enzymes were inhibited by yeast mannan. Yeast mannan inhibited the proteolytic activity of the native enzyme more than that of the heat-treated

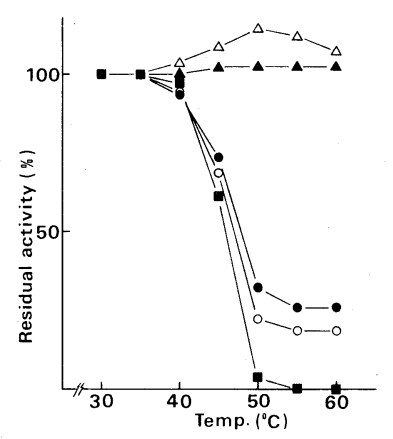

FIG. 3. Thermostability of Activity on YCW.

Zymolyase B solution $(50 \mu \mathrm{g} / \mathrm{ml}$, in $0.05 \mathrm{M}$ Tris buffer, $\mathrm{pH}$ 7.5) was incubated at the indicated temperature for 15 min, and then residual activity was assayed. Peptidemannan releasing activity and proteolytic activity were determined with $25 \mu \mathrm{g}$ of enzyme per $6 \mathrm{ml}$ of reaction mixture under the standard assay conditions. Lytic activity was determined in the presence of Zymolyase A $(5 \mu \mathrm{g} /$ $10 \mathrm{ml}$ ) with $5 \mu \mathrm{g}$ of enzyme per $10 \mathrm{ml}$ of reaction mixture under the standard assay conditions. $\mathbf{O}$, release of amino acid substances; $\bigcirc$, carbohydrate release; $\boldsymbol{\Delta}$, proteolytic activity on HPA; $\triangle$, proteolytic activity on casein; $\square$ lytic activity.

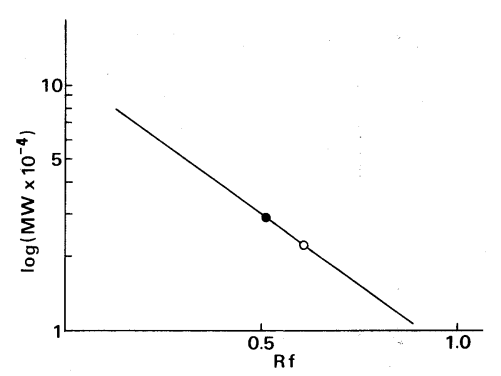

FIG. 4. Molecular Weights of Native and Heat-treated Enzymes.

Molecular weight was estimated by SDS gel electrophoresis with bovine albumin (MW 67,000), chymotrypsinogen- $A$ (MW 25,000) and cytochrome $c$ (MW 12,400) as standards. , native enzyme (MW 29,000); $\bigcirc$, heattreated enzyme (MW 22,500). 
TABle II. Amino Acid Compositions of Native AND Heat-Treated ENZYMes

\begin{tabular}{|c|c|c|}
\hline \multirow{2}{*}{ Amino acid } & \multicolumn{2}{|c|}{$\begin{array}{c}\text { Residues per molecule of } \\
\text { enzyme }\end{array}$} \\
\hline & Native & Heat-treated \\
\hline Trp & 7 & 4 \\
\hline Lys & 8 & 3 \\
\hline His & 2 & 2 \\
\hline Arg & 13 & 10 \\
\hline Asp & 30 & 20 \\
\hline Thr & 17 & 12 \\
\hline Ser & 24 & 21 \\
\hline Glu & 16 & 11 \\
\hline Pro & 10 & 10 \\
\hline Gly & 46 & 41 \\
\hline Ala & 37 & 26 \\
\hline Cys* & 10 & 6 \\
\hline Val & 27 & 23 \\
\hline Met & 2 & 1 \\
\hline ILeu & 8 & 7 \\
\hline Leu & 14 & 8 \\
\hline Tyr & 5 & 5 \\
\hline Phe & 7 & 5 \\
\hline Total & 283 & 215 \\
\hline
\end{tabular}

* As cysteic acid.

enzyme for both substrates. Moreover, it in hibited the activities of both enzymes on HPA more than those on casein. Table III shows the effects of sugars on the inhibition by yeast mannan. All sugars tested decreased the inhibition by yeast mannan, $\alpha$-methylmannoside being the most effective. The inhibitory effect of yeast mannan on the heat-treated enzyme was not affected by the addition of sugar. As shown in Fig. 6, yeast mannan caused noncompetitive inhibition of the native enzyme, but competitive inhibition of the heat-treated one.

Effect of modification of tryptophan residues of Zymolyase $B$ on its activity

As shown in Table IV, four Trp residues per molecule of the enzyme were oxidized by NBS. Various activities of modified enzymes with different numbers of oxidized Trp residues were examined. As shown in Fig. 7, the proteolytic activity on HPA decreased linearly with an increase in the number of oxidized Trp

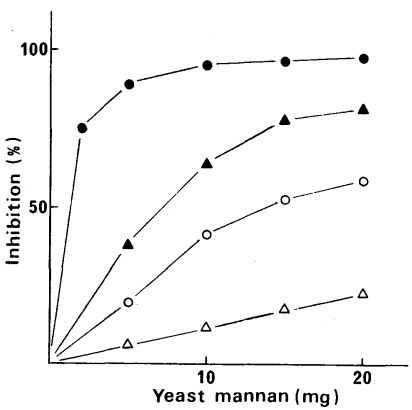

FIG. 5. Effect of Yeast Mannan on Proteolytic Activity. Proteolytic activity was measured in the presence of the indicated amounts of yeast mannan with $20 \mu \mathrm{g}$ of enzyme per $6 \mathrm{ml}$ of reaction mixture under the standard assay

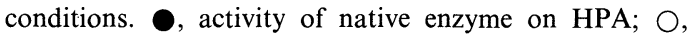
activity of native enzyme on casein; $\boldsymbol{\Delta}$, activity of heattreated enzyme on HPA; $\triangle$, activity of heat-treated enzyme on casein.

TABle III. EFFECTS OF Sugars ON INHIBITION OF PROTEOLYTIC ACTIVITY BY Yeast ManNaN

Proteolytic activity on HPA was determined in the presence of $20 \mathrm{mg}$ of each sugar with or without $5 \mathrm{mg}$ of yeast mannan using $20 \mu \mathrm{g}$ of native enzyme per $6 \mathrm{ml}$ of reaction mixture under the standard assay conditions. The activity on casein was determined in the presence of $20 \mathrm{mg}$ of each sugar with or without $10 \mathrm{mg}$ of yeast mannan using $20 \mu \mathrm{g}$ of native enzyme per $6 \mathrm{ml}$ of reaction mixture under the standard assay conditions.

\begin{tabular}{lcc}
\hline \multirow{2}{*}{ Sugar } & \multicolumn{2}{c}{ Relative inhibition $(\%)$} \\
\cline { 2 - 3 } & On HPA & On casein \\
\hline None & 100 & 100 \\
Glucose & 94 & 87 \\
Mannose & 82 & 72 \\
Xylose & 100 & 90 \\
Maltose & 95 & 87 \\
Cellobiose & 95 & 87 \\
$\alpha$-Methylmannoside & 72 & 63 \\
\hline
\end{tabular}

residues, while that on casein did not. Figure 8 shows that the inhibitory effect of yeast mannan on the proteolytic activity on casein decreased with an increase in the number of oxidized Trp residues to almost the same level as that of the heat-treated enzyme and that the activity releasing peptide-mannan from YCW also decreased with an increase in the number of oxidized Trp residues to the same level as 

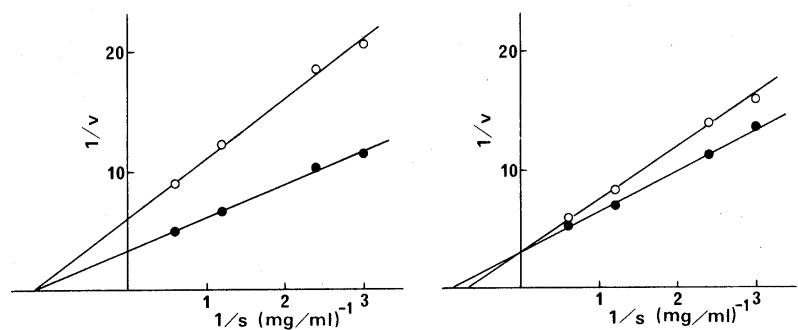

FIG. 6. Lineweaver-Burk Plot of Proteolysis of Casein by Native or Heat-treated Enzyme.

A reaction mixture consisting of $4 \mathrm{ml}$ of casein solution of various concentrations (in $0.05 \mathrm{M}$ Tris buffer, $\mathrm{pH}$ $7.5), 1 \mathrm{ml}$ of water or mannan solution $(5 \mathrm{mg} / \mathrm{ml})$ and $1 \mathrm{ml}$ of enzyme solution $(20 \mu \mathrm{g} / \mathrm{ml})$ was incubated at $30^{\circ} \mathrm{C}$ for $1 \mathrm{hr}$. Then activity was measured as described under MATERIALS AND METHODS. The reaction velocity (v) is expressed as increase in OD at $660 \mathrm{~nm}$ per hr. native enzyme, $K m=0.84 \mathrm{mg} / \mathrm{ml}, K i=1.1 \mathrm{mg} / \mathrm{ml}$. Right: heat-treated enzyme, $K m=1.1 \mathrm{mg} / \mathrm{ml}, K i=2.7 \mathrm{mg} / \mathrm{ml}$.

\section{TABLE IV. MODIFICATION OF TRYPTOPHAN RESIDUES OF ZYMOLYASE B}

Trp residues of Zymolyase B were oxidized with NBS under the conditions described under MATERIALS AND METHODS.

\begin{tabular}{ccc}
$\begin{array}{c}\text { Volume of } 0.01 \mathrm{M} \mathrm{NBS} \\
\text { soln. added }(\mu \mathrm{l})\end{array}$ & OD at $280 \mathrm{~nm}$ & $\begin{array}{c}\text { Number of Trp } \\
\text { oxidized } \\
\text { per mol. }\end{array}$ \\
\hline 0 & 0.570 & 0 \\
10 & 0.516 & 0.9 \\
20 & 0.451 & 2.0 \\
30 & 0.398 & 2.9 \\
40 & 0.351 & 3.7 \\
50 & 0.321 & 4.2 \\
60 & 0.315 & 4.3 \\
70 & 0.315 & 4.3 \\
\hline
\end{tabular}

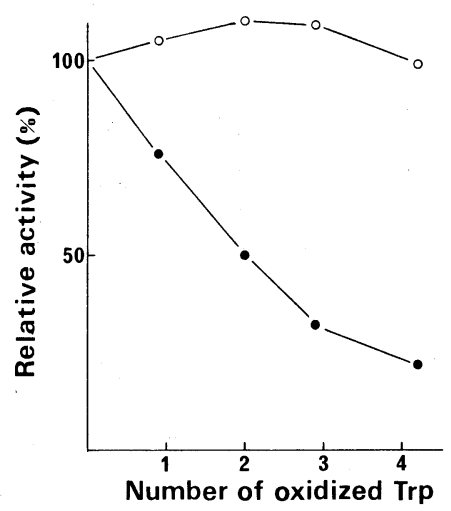

FIG. 7. Proteolytic Activity of Oxidized Enzyme.

Proteolytic activities on HPA and casein were determined using about $20 \mu \mathrm{g}$ of each oxidized enzyme (as native enzyme) per $6 \mathrm{ml}$ of reaction mixture under the standard assay conditions. activity on HPA; $\bigcirc$, activity on casein.

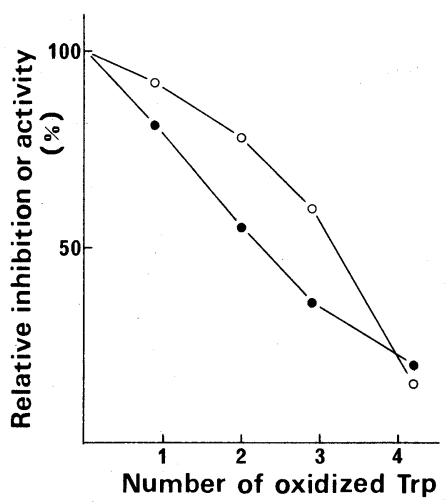

FIG. 8. Inhibitory Effect of Yeast Mannan on Proteolytic Activity of Oxidized Enzyme.

Proteolytic activity on casein was determined with or without $0.17 \%$ yeast mannan using about $20 \mu \mathrm{g}$ of each oxidized enzyme (as native enzyme) per $6 \mathrm{ml}$ of reaction mixture under the standard assay conditions. Release of peptide-mannan from YCW was also determined using the same amount of each oxidized enzyme by measuring the release of carbohydrates under the standard assay conditions. inhibitory effect of yeast mannan; $\bigcirc$, release of peptide-mannan.

that of the heat-treated enzyme. Completely oxidized enzyme did not show any lytic activity on viable yeast cells in the presence of Zymolyase A.

\section{DISCUSSION}

Zymolyase B decreased the turbidity of a YCW suspension by about $50 \%$, but did not decrease the number of $\mathrm{YCW}$ as in the case of viable cells. ${ }^{1)}$ It released peptide-mannan with 
a MW of about 180,000 from YCW although it had no mannanase activity. The action of Zymolyase B on YCW was not affected appreciably by $\mathrm{pH}$, suggesting that the enzyme preferentially breaks down a certain portion of peptides of YCW and then its proteolytic activity is repressed. The thermostability of the activity on YCW differed from that of proteolytic activity: after incubation at $55^{\circ} \mathrm{C}$ for $15 \mathrm{~min}$ it showed very low activity on $\mathrm{YCW}$ and no lytic activity on viable yeast cells in the presence of Zymolyase A, but retained full proteolytic activity. On this treatment, the MW of the enzyme decreased from 29,000 to 22,500 and the enzyme lost 68 of its amino acid residues. Heat-treated and native enzymes differed not only in their activities on YCW but also in their sensitivities to yeast mannan: the proteolytic activities of both enzymes were inhibited by yeast mannan, but the native enzyme was inhibited 4 times more than the heat-treated one. The inhibition by yeast mannan of the native enzyme was considerably suppressed by addition of $\alpha$-methylmannoside. The mode of the inhibition by yeast mannan of the native enzyme also differed from that of the heat-treated enzyme; that is, noncompetitive inhibition with the native enzyme, but competitive inhibition with the heat-treated enzyme. As the yeast mannan preparation used contained about $6 \%$ protein, the competitive inhibition by yeast mannan of the heat-treated enzyme may be caused by the peptide included in the preparation as a substrate analogue. The noncompetitive inhibition of the native enzyme suggests that the enzyme has an affinity site for yeast mannan, that allosterically affects the active site. This relation of Zymolyase $B$ and yeast mannan resembles that of an allosteric enzyme and its effector; just as Zymolyase-B is desensitized to yeast mannan by heat-treatment, so is the allosteric enzyme. ${ }^{16)}$ The decrease in sensitivity of Zymolyase B to yeast mannan on heattreatment might be due to detachment of a peptide chain containing the affinity site for yeast mannan by preferential self digestion under the treatment conditions. Chemical mo- dification of a certain amino acid residue at the effector binding site is reported to desensitize the allosteric enzyme. ${ }^{16,17)}$ The difference spectrum of the native enzyme-yeast mannan mixture against the heat-treated enzyme-yeast mannan mixture in the UV region has three peaks at 274, 283 and $291 \mathrm{~nm}$, chracteristic of the difference spectrum of tryptophan. ${ }^{18)}$ This suggested that Trp residues in Zymolyase B participate in yeast mannan binding. Four of seven Trp residues in the enzyme were oxidized by tratment with NBS, and the oxidized enzyme showed the same susceptibility to yeast mannan and the same activity on YCW as the heat-treated enzyme. The difference in the proteolytic activities on HPA of the oxidized and heat-treated enzymes indicates that the yeast mannan binding site is necessary for the proteolytic action of Zymolyase B on insoluble substrates. The inability of the oxidized enzyme to act on HPA may be due to steric hindrance by a peptide chain containing a modified site for mannan binding, and the heat-treated enzyme free from this peptide chain may be able to act on HPA.

From the above results, it was concluded that the specific action of Zymolyase $B$ on yeast cell walls depends on its affinity for yeast mannan. Zymolyase B can take two forms, a free form and a bound form to yeast mannan, and only in the latter form is it able to act on the yeast cell wall. On the surface of the cell wall of brewer's yeast obtained from a brewhouse, blocks of manno-protein may be arranged in such a manner that mannan and protein parts are directed to the outside and inside, respectively, preventing penetration of an exogeneous enzyme. Zymolyase B may bind to the mannan part, change its conformation and cause the protein part to release peptidemannan blocks. Zymolyase B differs greatly from the allosteric enzyme in that its binding to yeast mannan results in a positive action on the yeast cell walls, although the binding decreases its proteolytic activity.

Acknowledgments. The author thanks Kirin Brewery Co., Ltd. for permission to publish this work, and Dr. Y. 
Yamamoto and Dr. Y. Kuroiwa, Director of the Research Laboratories of Kirin Brewery Co., for their encouragement.

\section{REFERENCES}

1) K. Kitamura, Agric. Biol. Chem., 46, 963 (1982).

2) M. L. Anson, J. Gen. Physiol., 22, 79 (1938).

3) J. E. Hodge and B. T. Hofreiter, "Methods in Carbohydrate Chemistry," Vol. 1, ed. by R. L. Whistler and M. L. Wolfrom, Academic Press Inc., New York, 1962, p. 388.

4) M. John, J. Schmidt and H. Dellweg, Monatsschr. Brau., 28, 14 (1975).

5) K. Kitamura, T. Kaneko and Y. Yamamoto, J. Gen. Appl. Microbiol., 20, 323 (1974).

6) O. H. Lowry, N. J. Rosebrough, A. L. Farr and R. J. Randall, J. Biol. Chem., 193, 265 (1951).

7) J. S. Sawardeker, J. H. Slonecker and A. Jeanes, Anal. Chem., 37, 1602 (1965).
8) K. Ohtani and A. Misaki, Agric. Biol. Chem., 44, 2029 (1980).

9) S. Moore, J. Biol. Chem., 238, 235 (1963).

10) H. Edelhoch, Biochemistry, 7, 1948 (1967).

11) T. F. Spande, N. M. Green and B. Witkop, Biochemistry, 5, 1926 (1966).

12) A. Patchornik, W. B. Lawson and B. Witkop, J. Am. Chem. Soc., 80, 4748 (1958).

13) K. Kitamura, T. Kaneko and Y. Yamamoto, J. Gen. Appl. Microbiol., 18, 57 (1972).

14) A. E. Clarke and B. A. Stone, Phytochemistry, 1, 175 (1962).

15) W. N. Haworth, J. Chem. Soc., 784 (1937).

16) J. P. Changeux, Cold Spring Harbor Symp. Quant. Biol., 26, 313 (1961).

17) J. C. Gerhart and A. B. Pardee, J. Biol. Chem., 237, 891 (1962).

18) K. Hayashi, T. Imoto and M. Funatsu, J. Biochem., 55, 516 (1964). 